\title{
ANALISIS PENENTUAN LOKASI RUMAH SAKIT TIPE C BARU MENGGUNAKAN METODE ANALYTICAL HIERARCHY PROCESS (AHP) DI KABUPATEN SUMEDANG
}

\author{
SKRIPSI \\ Diajukan Untuk Memenuhi Sebagian dari \\ Syarat Untuk Memperoleh Gelar Sarjana Pendidikan Geografi \\ Prodi Pendidikan Geografi

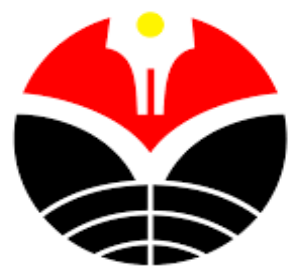

Oleh

Andre Wirapati Prasasta Natsir

NIM. 1602400

\section{PROGRAM STUDI PENDIDIKAN GEOGRAFI \\ DEPARTEMEN PENDIDIKAN GEOGRAFI \\ FAKULTAS PENDIDIKAN ILMU PENGETAHUAN SOSIAL UNIVERSITAS PENDIDIKAN INDONESIA}


ANALISIS PENENTUAN LOKASI RUMAH SAKIT TIPE C BARU

MENGGUNAKAN METODE ANALYTICAL HIERARCHY PROCESS

(AHP)

DI KABUPATEN SUMEDANG

Oleh

Andre Wirapati Prasasta Natsir

Sebuah skripsi yang diajukan untuk memenuhi salah satu syarat memperoleh gelar Sarjana Pendidikan (S.Pd) pada Program Studi Pendidikan Geografi

(C) Andre Wirapati Prasasta Natsir

Universitas Pendidikan Indonesia

Desember 2020

Hak cipta dilindungi oleh Undang-undang

Skripsi ini tidak boleh diperbanyak seluruh atau sebagian,

Dengan dicetak ulang, difoto kopi, atau cara lainnya tanpa ijin dari penulis

Andre Wirapati Prasasta Natsir, 2020

ANALISIS PENENTUAN LOKASI RUMAH SAKIT TIPE C BARU MENGGUNAKAN METODE

ANALYTICAL HIERARCHY PROCESS (AHP) DI KABUPATEN SUMEDANG

Universitas Pendidikan Indonesia | repository.upi.edu | perpustakaan.upi.edu 
LEMBAR PENGESAHAN

ANDRE WIRAPATI PRASASTA NATSIR

(1602400)

ANALISIS PENENTUAN LOKASI RUMAH SAKIT TIPE C BARU MENGGUNAKAN METODE ANALYTICAL HIERARCHY PROCESS

(AHP)

DI KABUPATEN SUMEDANG

Disetujui dan disahkan oleh pembimbing:

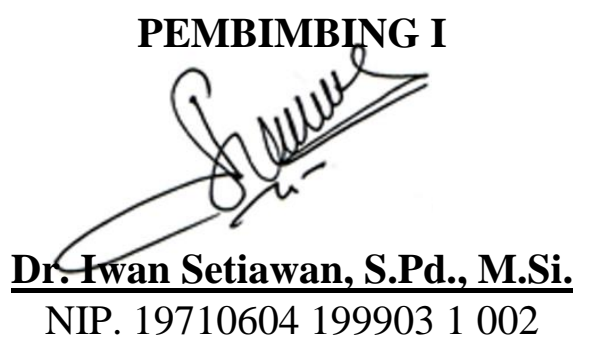

PEMBIMBING II<smiles>C=CCCCC(C)C(C)(C)C</smiles>

Dr. Lili Somantri, S.Pd., M.Si.

NIP. 197902262005011008

Mengetahui,

Ketua Departemen Pendidikan Geografi

Fakultas Pendidikan Ilmu Pengetahuan Sosial

Universitas Pendidikan Indonesia

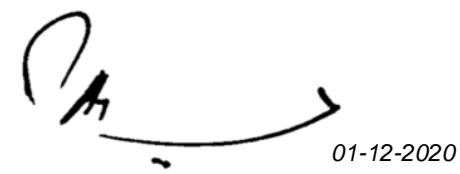

Dr. Ahmad Yani, M.Si.

NIP. 196708121997021001 


\title{
ANALISIS PENENTUAN LOKASI RUMAH SAKIT TIPE C BARU MENGGUNAKAN METODE ANALYTICAL HIERARCHY PROCESS \\ (AHP) \\ DI KABUPATEN SUMEDANG
}

Oleh:

\author{
Natsir, Andre Wirapati Prasasta, I. Setiawan, L. Somantri.*) \\ Departemen Pendidikan Geografi, Fakultas Pendidikan Ilmu Pengetahuan Sosial \\ Universitas Pendidikan Indonesia
}

\begin{abstract}
ABSTRAK
Laju pertumbuhan penduduk yang terus meningkat berjalan seiringan dengan permintaan masyarakat pada suatu fasilitas pelayanan di bidang kesehatan, khususnya rumah sakit. Kabupaten Sumedang merupakan salah satu wilayah di Provinsi Jawa Barat, Indonesia yang memiliki jumlah penduduk cukup tinggi. Namun berdasarkan standar rasio tempat tidur rumah sakit dengan jumlah penduduk 1:1.000 yang dirilis oleh Kementerian Kesehatan, Kabupaten Sumedang belum memenuhi standar rasio tersebut. Penelitian ini bertujuan untuk menganalisis kondisi sebaran rumah sakit eksisting dan menentukan alternatif lokasi rumah sakit tipe $\mathrm{C}$ baru yang ideal. Metode yang digunakan adalah metode Sistem Informasi Geografis dengan pembobotan AHP (Analytical Hierarchy Process). Teknik analisis data berupa analisis spasial deskriptif, network analyst service area dan overlay. Parameter penentuan lokasi rumah sakit baru dalam penelitian ini adalah penggunaan lahan, kemiringan lereng, jaringan jalan, kepadatan penduduk, daerah potensi banjir, dan daerah potensi longsor. Hasil penelitian menunjukan bahwa kondisi sebaran rumah sakit eksisting mampu menjangkau 13 Kecamatan dari 26 Kecamatan di Kabupaten Sumedang berdasarkan radius $10 \mathrm{~km}$. Alternatif lokasi rumah sakit baru terbagi menjadi lima kelas yakni klasifikasi sangat tidak sesuai tertinggi berada di Kecamatan Buahdua dengan luas $73,27 \mathrm{~km}^{2}$, klasifikasi tidak sesuai tertinggi berada di Kecamatan Jatigede dengan luas 47,74 $\mathrm{km}^{2}$, klasifikasi agak sesuai tertinggi berada di Kecamatan Buahdua dengan luas 34,63 km², klasifikasi sesuai tertinggi berada di Kecamatan Sumedang Utara dengan luas $11,33 \mathrm{~km}^{2}$, dan klasifikasi sangat sesuai tertinggi berada di Kecamatan Jatinangor dengan luas $6,83 \mathrm{~km}^{2}$. Penelitian ini bermanfaat bagi masyarakat, pihak swasta, hingga pemerintah yang berkaitan dengan perencanaan pembangunan rumah sakit baru di suatu daerah.
\end{abstract}

Kata Kunci: lokasi, rumah sakit baru, AHP, SIG.

*) Penulis Penanggung Jawab 


\title{
ANALYSIS OF LOCATION FOR NEW TYPE C HOSPITAL CONSTRUCTION \\ USING ANALYTICAL HIERARCHY PROCESS (AHP) IN SUMEDANG REGENCY \\ By:
}

\author{
Natsir, Andre Wirapati Prasasta, I. Setiawan, L. Somantri*) \\ Department of Geography Education, Faculty of Social Sciences Education, \\ Indonesia University of Education
}

\begin{abstract}
The increase of population grows together alongside demands for health related facilities, especially hospitals. Sumedang is a regency in West Java Province, Indonesia, that has a pretty dense population. Based on standard ratio of 1:1,000 hospitals to population which was released by Ministry of Health, Sumedang Regency has not meet the requirements yet. The objectives of this research are to analyze existing hospitals distribution condition and to consider some alternative locations for new ideal type $C$ hospitals. Methods that are used for this research are Geographic Information System (GIS) concentrating on Analytical Hierarchy Proccess (AHP). These data are analyzed with spatial descriptive technique, network analyst service area, and overlay technique. Hospitals that were observed were picked under these parameters; (1) the land use, (2) the slope, (3) the road network, (4) population density, (5) potential flooding areas, and (6) potential landslide areas. Result shows that existing hospitals in current distribution would be able to provide care to 14 out of 26 districts in Sumedang within 10 kilometers radius. Alternative locations for new hospitals are divided into 5 classes; (1) highest very unsuitable, located in Buahdua District with area of $73.27 \mathrm{~km} 2$, (2) highest unsuitable, located in Jatigede District with area of $47.74 \mathrm{~km} 2$, (3) highest moderately suitable, located in Buahdua District with area of $34.63 \mathrm{~km} 2$, (4) highest suitable, located in North Sumedang District with area of 11.33 $\mathrm{km} 2$, and (5) highest very suitable, located in Jatinangor District with area of $6.83 \mathrm{~km} 2$. This research is expected to be helpful for the community, including all kind of providers and caterers for the hospitals. Also to give some new perspectives regarding new hospital construction planning for the government officials.
\end{abstract}

Keywords: location, new hospital, AHP, GIS.

*) Author 


\section{DAFTAR ISI}

LEMBAR PENGESAHAN

PERNYATAAN KEASLIAN NASKAH PENELITIAN..Error! Bookmark not defined.

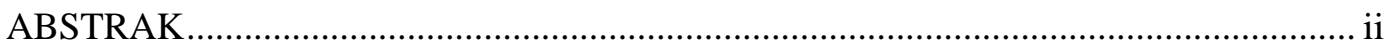

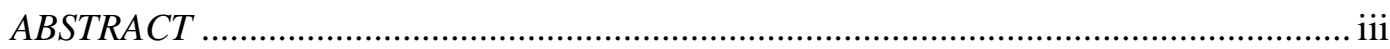

KATA PENGANTAR ………….......................................Error! Bookmark not defined.

UCAPAN TERIMAKASIH ..............................................Error! Bookmark not defined.

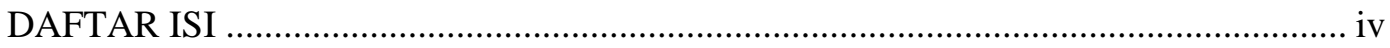

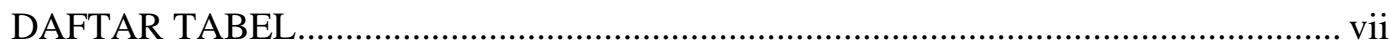

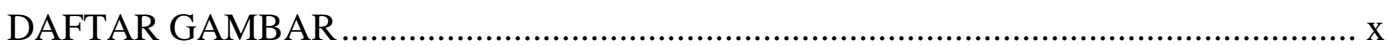

BAB I PENDAHULUAN................................................... Error! Bookmark not defined.

1.1 Latar Belakang ......................................................Error! Bookmark not defined.

1.2 Rumusan Masalah..............................................Error! Bookmark not defined.

1.3 Tujuan Penelitian .................................................Error! Bookmark not defined.

1.4 Manfaat Penelitian .............................................Error! Bookmark not defined.

1.5 Definisi Operasional ...........................................Error! Bookmark not defined.

1.6 Struktur Organisasi Skripsi .................................Error! Bookmark not defined.

BAB II TINJAUAN PUSTAKA .........................................Error! Bookmark not defined.

2.1 Konsep Lokasi ....................................................Error! Bookmark not defined.

2.1.1 Pengertian Lokasi.......................................Error! Bookmark not defined.

2.1.2 Teori Lokasi ................................................Error! Bookmark not defined.

2.1.3 Faktor Penentu Lokasi Fasilitas Umum.....Error! Bookmark not defined.

2.1.4 Faktor Penentu Lokasi Rumah Sakit...........Error! Bookmark not defined.

2.2 Jangkauan Pelayanan .........................................Error! Bookmark not defined.

2.3 Aksesibilitas ........................................................Error! Bookmark not defined.

2.4 Konsep Pelayanan Kesehatan .............................Error! Bookmark not defined.

2.5 Pengertian dan Jenis Fasilitas Pelayanan Kesehatan ....... Error! Bookmark not defined.

2.6 Rumah Sakit Error! Bookmark not defined.

2.6.1 Pengertian Rumah Sakit. Error! Bookmark not defined.

2.6.2 Tugas dan Fungsi Rumah Sakit Error! Bookmark not defined.

2.6.3 Landasan Yuridis Dalam Menentukan Lokasi Rumah Sakit Error! Bookmark not defined.

2.6.4 Sintesis Faktor Penentu Lokasi Rumah Sakit Error! Bookmark not defined.

2.7 Sistem Informasi Geografis .Error! Bookmark not defined. 
2.7.1 Pengertian Sistem Informasi Geografis .....Error! Bookmark not defined.

2.7.2 Unsur dan Komponen Sistem Informasi Geografis . Error! Bookmark not defined.

2.7.3 Sistem Informasi Geografis di Bidang Kesehatan ... Error! Bookmark not defined.

2.7.4 Network Analyst Dalam Sistem Informasi Geografis ....Error! Bookmark not defined.

2.8 Analytical Hierarchy Process.

...Error! Bookmark not defined.

2.8.1 Pengertian AHP (Analytical Hierarchy Process) ..... Error! Bookmark not defined.

2.8.2 Prosedur AHP (Analytical Hierarchy Process) ........ Error! Bookmark not defined.

2.8.3 Keuntungan/Kelebihan AHP (Analytical Hierarchy Process) ............ Error! Bookmark not defined.

2.8.4 Tahapan AHP (Analytical Hierarchy Process) ........ Error! Bookmark not defined.

2.8.5 Aksioma AHP (Analytical Hierarchy Process)........ Error! Bookmark not defined.

2.8.6 Aplikasi AHP Dalam Kehidupan. ..Error! Bookmark not defined.

2.9 Penelitian Terdahulu Error! Bookmark not defined.

BAB III METODOLOGI PENELITIAN ...Error! Bookmark not defined.

3.1 Lokasi Penelitian ..Error! Bookmark not defined.

3.2 Desain Penelitian Error! Bookmark not defined.

3.3 Metode Penelitian Error! Bookmark not defined.

3.4 Pendekatan Geografi Error! Bookmark not defined.

3.5 Alat dan Bahan Penelitian. Error! Bookmark not defined.

3.6 Variabel Penelitian Error! Bookmark not defined.

3.7 Populasi dan Sampel Error! Bookmark not defined.

3.7.1 Populasi Error! Bookmark not defined.

3.7.2 Sampel Error! Bookmark not defined.

3.8 Teknik Pengumpulan Data Error! Bookmark not defined.

3.9 Teknik Analisis Data ..Error! Bookmark not defined.

3.9.1 Kondisi Sebaran Rumah Sakit Yang Telah Ada...... Error! Bookmark not defined.

3.9.2 Alternatif Lahan Lokasi Rumah Sakit Tipe C Baru Berdasarkan Klasifikasi ..Error! Bookmark not defined.

3.10 Bagan Alur Penelitian ..Error! Bookmark not defined. BAB IV HASIL DAN PEMBAHASAN Error! Bookmark not defined. 
4.1 Gambaran Umum Lokasi Penelitian Error! Bookmark not defined.

4.1.1 Letak dan Luas Error! Bookmark not defined.

4.1.2 Kondisi Fisik. Error! Bookmark not defined.

4.1.3 Demografi Error! Bookmark not defined.

4.2 Temuan Penelitian Error! Bookmark not defined.

4.2.1 Kondisi Sebaran Rumah Sakit Yang Telah Ada...... Error! Bookmark not defined.

4.2.2 Alternatif Lahan Lokasi Rumah Sakit Tipe C Baru Berdasarkan Klasifikasi ..Error! Bookmark not defined.

4.3 Pembahasan ...Error! Bookmark not defined.

4.3.1 Kondisi Sebaran Rumah Sakit Yang Telah Ada...... Error! Bookmark not defined.

4.3.2 Alternatif Lahan Lokasi Rumah Sakit Tipe C Baru Berdasarkan Klasifikasi Error! Bookmark not defined.

BAB V KESIMPULAN DAN REKOMENDASI Error! Bookmark not defined.

5.1 Kesimpulan Error! Bookmark not defined.

5.2 Implikasi Error! Bookmark not defined.

5.3 Rekomendasi Error! Bookmark not defined.

DAFTAR PUSTAKA $\mathrm{XV}$ Error! Bookmark not defined. 


\section{DAFTAR TABEL}

Tabel 1.1 Data Rumah Sakit di Kabupaten Sumedang Error! Bookmark not defined.

Tabel 2.1 Kajian Teori Faktor-Faktor Penentu Lokasi Fasilitas Umum \& Rumah Sakit Error! Bookmark not defined.

Tabel 2.2 Sintesis Tinjauan Pustaka Faktor Penentu Lokasi Rumah Sakit ... Error! Bookmark not defined.

Tabel 2.3 Faktor Penentu Lokasi Rumah Sakit .....Error! Bookmark not defined. Tabel 2.4 Nilai Matriks Perbandingan AHP ...........Error! Bookmark not defined. Tabel 2.5 Matriks Perbandingan AHP Error! Bookmark not defined.

Tabel 2.6 Penelitian Terdahulu Error! Bookmark not defined.

Tabel 3.1 Variabel dan Indikator Penelitian Error! Bookmark not defined.

Tabel 3.2 Matriks Perbandingan Kriteria Error! Bookmark not defined.

Tabel 3.3 Matriks Eigenvector. Error! Bookmark not defined.

Tabel 3.4 Vector Jumlah Tertimbang Error! Bookmark not defined.

Tabel 3.5 Hasil Vektor Konsistensi Error! Bookmark not defined.

Tabel 3.6 Nilai Konsistensi Rasio Error! Bookmark not defined.

Tabel 3.7 Hasil Perhitungan Bobot Kriteria Error! Bookmark not defined. Tabel 3.8 Bobot Sub Kriteria Penggunaan Lahan .Error! Bookmark not defined. Tabel 3.9 Bobot Sub Kriteria Kelas Jaringan JalanError! Bookmark not defined. Tabel 3.10 Bobot Sub Kriteria Daerah Potensi Longsor ..... Error! Bookmark not defined.

Tabel 3.11 Bobot Sub Kriteria Daerah Potensi Banjir Error! Bookmark not defined.

Tabel 3.12 Bobot Sub Kriteria Kemiringan Lahan Error! Bookmark not defined. Tabel 3.13 Bobot Sub Kriteria Jarak TPA \& TPS .Error! Bookmark not defined. Tabel 3.14 Bobot Sub Kriteria Tingkat Kebisingan Error! Bookmark not defined.

Tabel 3.15 Bobot Sub Kriteria Tingkat Polusi Udara.... Error! Bookmark not defined.

Tabel 3.16 Bobot Kriteria Utama. Error! Bookmark not defined.

Tabel 3.17 Perhitungan Jumlah Skor Minimal ......Error! Bookmark not defined. Tabel 3.18 Perhitungan Jumlah Skor Maksimal ....Error! Bookmark not defined. Tabel 3.19 Klasifikasi Bobot Akhir Alternatif Lokasi Rumah Sakit Baru .... Error! Bookmark not defined.

Tabel 4.1 Luas Wilayah Menurut Kecamatan di Kabupaten Sumedang ....... Error! Bookmark not defined.

Tabel 4.2 Suhu Rata-Rata Kabupaten Sumedang Tahun 2018 ...Error! Bookmark not defined. 
Tabel 4.3 Intensitas Curah Hujan Per-Kecamatan di Kabupaten Sumedang. Error! Bookmark not defined.

Tabel 4.4 Penggunaan Lahan di Kabupaten Sumedang....... Error! Bookmark not defined.

Tabel 4.5 Kemiringan Lereng di Kabupaten Sumedang...... Error! Bookmark not defined.

Tabel 4.6 Sebaran Luas dan Jenis Tanah di Kabupaten Sumedang Error! Bookmark not defined.

Tabel 4.7 Jenis Batuan di Kabupaten Sumedang....Error! Bookmark not defined. Tabel 4.8 DAS dan Sub DAS di Kabupaten Sumedang ...... Error! Bookmark not defined.

Tabel 4.9 Jumlah dan Rasio Jenis Kelamin Penduduk di Kabupaten Sumedang Error! Bookmark not defined.

Tabel 4.10 Laju Pertumbuhan Penduduk di Kabupaten Sumedang Error! Bookmark not defined.

Tabel 4.11 Jangkauan Layanan Rumah Sakit Eksisting di Kabupaten Sumedang ..Error! Bookmark not defined.

Tabel 4.12 Luas Jangkauan Layanan RSUD Kabupaten Sumedang Error! Bookmark not defined.

Tabel 4.13 Luas Jangkauan Layanan RSU Pakuwon Kabupaten Sumedang Error! Bookmark not defined.

Tabel 4.14 Luas Jangkauan Layanan RS Harapan Keluarga Error! Bookmark not defined.

Tabel 4.15 Fungsi dan Status Jalan di Sekitar Rumah Sakit Kabupaten Sumedang Error! Bookmark not defined.

Tabel 4.16 Jenis dan Jumlah Trayek Angkutan Umum Yang Melintasi Rumah Sakit Eksisting di Kabupaten Sumedang ...............Error! Bookmark not defined. Tabel 4.17 Luasan Penggunaan Lahan di Kabupaten SumedangError! Bookmark not defined.

Tabel 4.18 Luasan Penggunaan Lahan Per-Kecamatan di Kabupaten Sumedang ..Error! Bookmark not defined.

Tabel 4.19 Karakteristik Kemiringan Lereng di Kabupaten Sumedang ........ Error! Bookmark not defined.

Tabel 4.20 Karakteristik Kemiringan Lereng Per-Kecamatan di Kabupaten

Sumedang Error! Bookmark not defined. Tabel 4.21 Kepadatan Penduduk di Kabupaten Sumedang . Error! Bookmark not defined.

Tabel 4.22 Kategori Tingkat Kepadatan Penduduk Per-Kecamatan di Kabupaten Sumedang Error! Bookmark not defined. Tabel 4.23 Kategori Potensi Longsor di Kabupaten Sumedang . Error! Bookmark not defined. 
Tabel 4.24 Kategori Potensi Longsor Per-Kecamatan di Kabupaten Sumedang Error! Bookmark not defined.

Tabel 4.25 Kategori Potensi Banjir di Kabupaten Sumedang .... Error! Bookmark not defined.

Tabel 4.26 Kategori Potensi Banjir Per-Kecamatan di Kabupaten Sumedang

Error! Bookmark not defined.

Tabel 4.27 Klasifikasi Kesesuaian Lahan Peruntukan Lokasi Rumah Sakit Baru

Error! Bookmark not defined.

Tabel 4.28 Luasan Hasil Overlay Peta Parameter Kesesuaian Lahan Lokasi

Rumah Sakit Baru

Error! Bookmark not defined.

Tabel 4.29 Luasan Klasifikasi Kesesuaian Lahan Lokasi Rumah Sakit Baru di

Kabupaten Sumedang .........................................Error! Bookmark not defined.

Tabel 4.30 Hasil Validasi Lapangan Kecamatan Jatigede... Error! Bookmark not defined.

Tabel 4.31 Hasil Validasi Lapangan Kecamatan Buahdua.. Error! Bookmark not defined.

Tabel 4.32 Hasil Validasi Lapangan Kecamatan Tanjungsari .... Error! Bookmark not defined.

Tabel 4.33 Hasil Validasi Lapangan Kecamatan Jatinunggal..... Error! Bookmark not defined.

Tabel 4.34 Hasil Validasi Lapangan Kecamatan Sukasari .. Error! Bookmark not defined.

Tabel 4.35 Hasil Validasi Lapangan Kecamatan Rancakalong .. Error! Bookmark not defined.

Tabel 4.36 Hasil Validasi Lapangan Kecamatan Cisitu ...... Error! Bookmark not defined.

Tabel 4.37 Hasil Validasi Lapangan Kecamatan Conggeang ..... Error! Bookmark not defined.

Tabel 4.38 Hasil Validasi Lapangan Kecamatan Tanjungkerta.. Error! Bookmark not defined.

Tabel 4.39 Hasil Validasi Lapangan Kecamatan Darmaraja Error! Bookmark not defined.

Tabel 4.40 Hasil Validasi Lapangan Kecamatan Cimalaka. Error! Bookmark not defined.

Tabel 4.41 Hasil Validasi Lapangan Kecamatan PamulihanError! Bookmark not defined.

Tabel 4.42 Hasil Validasi Lapangan Kecamatan Paseh....... Error! Bookmark not defined.

Tabel 4.43 Hasil Validasi Lapangan Kecamatan Sumedang Selatan ............ Error! Bookmark not defined.

Tabel 4.44 Hasil Validasi Lapangan Kecamatan Tomo ...... Error! Bookmark not defined. 


\section{DAFTAR GAMBAR}

Gambar 1.1 Rasio Ketersediaan Tempat Tidur Rumah Sakit Dengan Jumlah Penduduk Berdasarkan Provinsi, 2018. Error! Bookmark not defined.

Gambar 3.1 Diagram Alir AHP Error! Bookmark not defined.

Gambar 4.1 Peta Administrasi Kabupaten Sumedang .93

Gambar 4.2 Peta Topografi Kabupaten SumedangError! Bookmark not defined.5

Gambar 4.3 Grafik Curah Hujan Berdasarkan Bulan di Kabupaten Sumedang Error! Bookmark not defined.

Gambar 4.4 Peta Curah Hujan Kabupaten Sumedang 102

Gambar 4.5 Peta Penggunaan Lahan Kabupaten Sumedang 104

Gambar 4.6 Peta Kemiringan Lereng Kabupaten Sumedang 107

Gambar 4.7 Peta Jenis Tanah Kabupaten Sumedang 109

Gambar 48 Peta Geologi Kabupaten Sumedang. .111

Gambar 4.9 Peta Hidrologi Kabupaten Sumedang 113

Gambar 4.10 Peta Persebaran Rumah Sakit Kabupaten Sumedang 117

Gambar 4.11 Peta Jangkauan Layanan Rumah Sakit Eksisting di Kabupaten

Sumedang 120

Gambar 4.12 Peta Jangkauan Layanan RSUD Kabupaten Sumedang ................124

Gambar 413 Peta Jangkauan Layanan RSU Pakuwon Kabupaten Sumedang ...125

Gambar 4.14 Peta Jangkauan Layanan RSU Harapan Keluarga Kabupaten

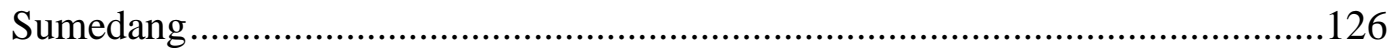

Gambar 4.15 Peta Penggunaan Lahan Kabupaten Sumedang ...........................136

Gambar 4.16 Peta Kemiringan Lereng Kabupaten Sumedang ............................142

Gambar 4.17 Peta Jaringan Jalan Kabupaten Sumedang ....................................143

Gambar 4.18 Peta Kepadatan Penduduk Kabupaten Sumedang..........................147

Gambar 4.19 Peta Potensi Longsor Kabupaten Sumedang ...............................152

Gambar 4.20 Peta Potensi Banjir Kabupaten Sumedang ....................................157

Gambar 4.21 Bobot Parameter/Kriteria Utama.......Error! Bookmark not defined.

Gambar 4.22 Bobot Sub Kriteria Penggunaan LahanError! Bookmark not

defined.

Gambar 4.23 Bobot Sub Kriteria Kelas Jaringan JalanError! Bookmark not defined.

Gambar 4.24 Bobot Sub Kriteria Kemiringan LerengError! Bookmark not defined.

Gambar 4.25 Bobot Sub Kriteria Kepadatan PendudukError! Bookmark not defined.

Gambar 4.26 Bobot Sub Kriteria Daerah Potensi LongsorError! Bookmark not defined.

Gambar 4.27 Bobot Sub Kriteria Daerah Potensi BanjirError! Bookmark not defined.

Gambar 4.28 Peta Kesesuaian Lahan Lokasi Rumah Sakit Baru Kabupaten Sumedang Error! Bookmark not defined. 
Gambar 4.29 Kondisi Penggunaan Lahan, Jaringan Jalan, dan Topografi Lokasi Validasi di Kecamatan Jatigede Error! Bookmark not defined. Gambar 4.30 Kondisi Penggunaan Lahan, Jaringan Jalan, dan Topografi Lokasi Validasi di Kecamatan Buahdua Error! Bookmark not defined. Gambar 4.31 Kondisi Penggunaan Lahan, Jaringan Jalan, dan Topografi Lokasi Validasi di Kecamatan Tanjungsari Error! Bookmark not defined. Gambar 4.32 Kondisi Penggunaan Lahan, Jaringan Jalan, dan Topografi Lokasi Validasi di Kecamatan Jatinunggal........................Error! Bookmark not defined. Gambar 4.33 Kondisi Penggunaan Lahan, Jaringan Jalan, dan Topografi Lokasi Validasi di Kecamatan Sukasari Error! Bookmark not defined. Gambar 4.34 Kondisi Penggunaan Lahan, Jaringan Jalan, dan Topografi Lokasi Validasi di Kecamatan Rancakalong Error! Bookmark not defined. Gambar 4.35 Kondisi Penggunaan Lahan, Jaringan Jalan, dan Topografi Lokasi Validasi di Kecamatan Cisitu. Error! Bookmark not defined. Gambar 4.36 Kondisi Penggunaan Lahan, Jaringan Jalan, dan Topografi Lokasi Validasi di Kecamatan Conggeang Error! Bookmark not defined. Gambar 4.37 Kondisi Penggunaan Lahan, Jaringan Jalan, dan Topografi Lokasi Validasi di Kecamatan Tanjungkerta Error! Bookmark not defined. Gambar 4.38 Kondisi Penggunaan Lahan, Jaringan Jalan, dan Topografi Lokasi Validasi di Kecamatan Darmaraja Error! Bookmark not defined. Gambar 4.39 Kondisi Penggunaan Lahan, Jaringan Jalan, dan Topografi Lokasi Validasi di Kecamatan Cimalaka Error! Bookmark not defined. Gambar 4.40 Kondisi Penggunaan Lahan, Jaringan Jalan, dan Topografi Lokasi Validasi di Kecamatan Pamulihan Error! Bookmark not defined. Gambar 4.41 Kondisi Penggunaan Lahan, Jaringan Jalan, dan Topografi Lokasi Validasi di Kecamatan Paseh Error! Bookmark not defined. Gambar 4.42 Kondisi Penggunaan Lahan, Jaringan Jalan, dan Topografi Lokasi Validasi di Kecamatan Sumedang Selatan. Error! Bookmark not defined. Gambar 4.43 Kondisi Penggunaan Lahan, Jaringan Jalan, dan Topografi Lokasi Validasi di Kecamatan Tomo. Error! Bookmark not defined. 


\section{DAFTAR PUSTAKA}

Ahmed, S., Ibrahim, R. F., \& Hefny, H. A. (2017). GIS-Based Network Analysis For The Roads Network of The Greater Cairo Area. CEUR Workshop Proceedings, 2144.

Andree Ekadinata, Dewi, S., Hadi, D. P., Nugroho, D. K., \& Johana, F. (2015). Sistem Informasi Geografis Untuk Pengelolaan Bentang Lahan Berbasis Sumber Daya Alam. Buku 1: Sistem Informasi Geografis dan Penginderaan Jauh Menggunakan ILWIS Open Source. In $D k$ (Vol. 53, Issue 9). World Agroforestry Centre. https://doi.org/10.1017/CBO9781107415324.004

Anggraini, P. (2013). Pengaruh Sebaran Lokasi Minimarket terhadap Jangkauan Pelayanan Pasar Tradisional di Kecamatan Banyumanik. Jurnal Pembangunan Wilayah \& Kota, $9 \quad$ (1), 97. https://doi.org/10.14710/pwk.v9i1.6530

Anwar, A. (1994). Pengantar Administrasi Kesehatan (Ketiga). Binarupa Aksara. Apidianto. (2017). Kajian Pembangunan Perumahan di Lahan Berkontur (pp. 114). Universitas Gunadarma.

Arikunto, S. (2006). Prosedur Penelitian Suatu Pendekatan Praktik. Rineka Cipta. Aronoff. (1989). Geographic Information Sistem: A Management Perpective. WDL Publication.

Atmanti, H. D. (2008). Anlytical Hierarchy Process Sebagai Model yang Luwes. Insahp 5, 17. https://doi.org/ISBN:978-979-97571-4-2

Azwar, A. (2002). Menjaga Mutu Pelayanan Kesehatan Aplikasi Prinsip Lingkaran Pemecahan Masalah. Pustaka Sinar Harapan.

Badan Pusat Statistik. (2019). Indonesia Dalam Angka.

Badan Standarisasi Nasional (2010). SNI 7645-2010 Tentang Klasifikasi Penutup Lahan.

Bafdal, N., Amaru, K., \& Pareira P, B. M. (2011). Buku Ajar Sistem Informasi Geografis (1st ed.). Jurusan Teknik dan Manajemen Industri Pertanian FTIP 


\section{UNPAD.}

Balitbangkes Kemenkes RI. (2014). Indeks Pembangunan Kesehatan Manusia (IPKM) 2013. In Kemenkes RI.

Bamba, G. (2018). Jangkauan Pelayanan Kesehatan Persalinan Rumah Sakit Swasta Bunda Margonda dan Tugu Ibu di Kota Depok. Prosiding Industrial Research Workshop and National Seminar, 9, 506-517.

Bintarto, R., \& Surastopo Hadisumarno. (1982). Metode Analisa Geografi. LP3ES. BPS Kabupaten Sumedang. (2019). Kabupaten Sumedang Dalam Angka.

Brissette, I., Casper, M., Huston, S. L., Jordan, M., Karns, B., Kippes, C., Kramer, M. R., Peacock, J. M., \& Vaughan, A. S. (2019). Application of Geographic Information Systems to Address Chronic Disease Priorities: Experiences in State and Local Health Departments. Preventing Chronic Disease, 16 (5), 18. https://doi.org/10.5888/pcd16.180674

Buana, P. W. (2010). Penentuan Rute Terpendek Pada Aplikasi Berbasis Peta. Universitas Udayana.

Bungin, B. (2017). Penelitian Kualitatif: Komunikasi, Ekonomi, Kebijakan Publik, dan Ilmu Sosial Lainnya.

Chavehpour, Y., Rashidian, A., Woldemichael, A., \& Takian, A. (2019). Inequality in Geographical Distribution of Hospitals and Hospital Beds in Densely Populated Metropolitan Cities of Iran. BMC Health Services Research, 19 (1), 1-8. https://doi.org/10.1186/s12913-019-4443-0

Eddy Prahasta. (2002). Konsep-Konsep Dasar Sistem Informasi Geografis. Informatika.

Fakhrurrazi, Mulyadi, \& Ismail, N. (2015). Pengetahuan dan Sikap Tenaga Kesehatan Rumah Sakit Umum Daerah (RSUD) Pidie Jaya Terhadap Kesiapsiagaan Dalam Menghadapi Risiko Bencana Banjir. Jurnal Ilmu Kebencanaan : Program Pascasarjana Unsyiah, Vol 2, No 4: November 2015, 1-12. http://www.jurnal.unsyiah.ac.id/JIKA/article/view/8152 
Fathoni, A. (2016). Analisa Faktor-Faktor Yang Mempengaruhi Pemilihan Lokasi Terhadap Tingkat Penjualan Usaha Jasa Mikro di Kbupaten Lamongan. $I(01), 22-33$.

Gistut. (1994). Sistem Informasi Geografis. Gramedia Pustaka Utama.

Grace, R., \& Saberi, M. (2018). The Value of Accessibility in Residential Property. ATRF 2018 - Australasian Transport Research Forum 2018, Proceedings, 117.

Hadi, P. L., Joewono, T. B., \& Santosa, W. (2013). Aksesibilitas menuju fasilitas kesehatan di kota bandung. Jurnal Transportasi, 13(3), 213-222.

Hakim, I. R. (2018). Studi Pelayanan Fasilitas Sosial Guna Menunjang Fungsi Pusat Pelayanan Kabupaten Bandung Barat.

Handy, S. L., \& Niemeier, D. A. (1997). Measuring accessibility: An exploration of issues and alternatives. Environment and Planning A, 29(7), 1175-1194. https://doi.org/10.1068/a291175

Hansen, W. G. (1959). Accessibility and Residential Growth. 1, 51.

Hariyono, W., Suryani, D., \& Wulandari, Y. (2014). Hubungan Antara Beban Kerja, Stres Kerja Dan Tingkat Konflik Dengan Kelelahan Kerja Perawat di Rumah Sakit Islam Yogyakarta PDHI Kota Yogyakarta. Jurnal Kesehatan Masyarakat (Journal of Public Health), 3(3), 25-36. https://doi.org/10.12928/kesmas.v3i3.1107

Haya, L. O. M. Y., Zubair, H., \& Salman, D. (2004). Analisis Kebijakan Pengelolaan Sumberdaya Terumbu Karang: Kasus Penangkapan Ikan yang Merusak (Sianida dan Bom) di Kepulauan Spermonde Sulawesi Selatan. 7587.

Ihsan. (1998). Studi Wilayah Pelayanan Pusat Belanja Wilayah di DKI Jakarta. Institut Teknologi Bandung.

Indriasih, E. (2008). Sistem Informasi Geografis (SIG) Dalam Bidang Kesehatan Masyarakat. Buletin Penelitian Sistem Kesehatan, 11(1), 99-104. 
Irma, A., Suasti, Y., \& Febriandi. (2018). Analisi Pola dan Jangkauan Pelayanan Publik di Kecamatan Rambah Samo Kabupaten Rokan Hulu-Riau. Buana, 2(3), 451-465.

Irwansyah, E. (2013). Sistem Informasi Geografis: Prinsip Dasar dan Pengembangan Aplikasi. Digibooks.

Isard, W. (2014). Location Theory and Trade Theory: Short-Run Analysys. 68(2), 305-320.

Jones, A. P., Bentham, G., Harrison, B. D. W., Jarvis, D., Badminton, R. M., \& Wareham, N. (1998). Accessibility and Health Service Utilisation For Asthma in Norfolk, England. Thorax, 51(SUPPL. 3), 312-317.

Jones, K. G., \& Simmons, J. W. (1993). Location, location, location: Analyzing The Retail Environment. Scarborough, Ont.

Jones, M., \& Hornby, F. W. (1991). An Introduction to Settlement Geography. Cambridge University Press.

Kara, F., \& Egresi, I. O. (2013). Social Science \& Medicine. International Journal of Scientific Knowledge, 3(2002), 16-27.

Kemenkes RI. (2019). Profil Kesehatan Indonesia 2018. http://www.depkes.go.id/resources/download/pusdatin/profil-kesehatanindonesia/Data-dan-Informasi_Profil-Kesehatan-Indonesia-2018.pdf

Keputusan Menteri Kesehatan Nomor 582 Tahun 1997 Tentang Pola Tarif Rumah Sakit.

Khadiyanto, P. (2005). Tata Ruang Berbasis Pada Kesesuaian Lahan. Badan Penerbit Universitas Diponegoro.

Klauss, G., Staub, L., Widmer, M., \& Busato, A. (2005). Hospital Service Areas A New Tool For Healthcare Planning in Switzerland. BMC Health Services Research, 5, 1-15. https://doi.org/10.1186/1472-6963-5-33

Komariyah, A., \& Satori, D. (2014). Metode Penelitian Kualitatif. Alfabeta. 
Krebs, C. J. (2002). Beyond population regulation and limitation. Wildlife Research, 29(1), 1-10. https://doi.org/10.1071/WR01074

Kusrini. (2007). Konsep dan Aplikasi Sistem Pendukung Keputussan (1st ed.).

Laksono, A. D. (2016). Aksesibilitas Pelayanan Kesehatan. January 2016, 20092011.

Lashari. (2011). Memilih Lokasi Untuk Bangunan Pada Lereng Perbukitan Aman Longsor (Studi Kasus di Semarang). Jurnal Teknik Sipil \& Perencanaan, 13(1), 1-8.

Li, X., \& Yeh, A. G. O. (2005). Integration of Genetic Algorithms and GIS For Optimal Location Search. International Journal of Geographical Information Science, 19(5), 581-601. https://doi.org/10.1080/13658810500032388

Litman, T. A. (2020a). Evaluating Accessibility for Transport Planning. January 2008. www.vtpi.org

Litman, T. A. (2020b). Evaluating Accessibility for Transport Planning.

Lupiyoadi, R., \& Hamdani, A. (2009). Manajemen Pemasaran Data. Salemba Empat.

Magdalena, H. (2017). Analisis Faktor - Faktor Pendukung Pengambilan Keputusan Memilih Rumah Sakit Rujukan Di Bangka Belitung Dengan Analitycal Hierarchy Process. Fountain of Informatics Journal, 2(2), 10. https://doi.org/10.21111/fij.v2i2.1196

Mantra, I. B. (1985). Pengantar Studi Demografi. Nurcahya.

Margono. (2004). Metodologi Penelitian Pendidikan. Rineka Cipta.

Masithah, R. A., Handayani, L., \& Warsiyah, W. (2018). Potensi Daerah Rawan Tanah Longsor Di Kecamatan Patuk, Yogyakarta Menggunakan Sistem Informasi Geografi (Sig). Jurnal Rekayasa Lingkungan, 18(2), 1-25. https://doi.org/10.37412/jrl.v18i2.32

Merieana Mahanani, \& Rahardjo, N. (2015). Penentuan Lokasi Puskesmas Baru 
Menggunakan Analitycal Hierarchy Process. Universitas Gadjah Mada.

Miarsih. (2009). Kajian Penentuan Lokasi Gedung SD-SMP Satu Atap di Kabupaten Demak. Universitas Diponegoro.

Moleong, L. (2002). Metode Penelitian Kualitatif. PT. Remaja Rosdakarya.

Muhamad Rasyidin, La Ode Ali Imran Ahmad, \& Farzan, A. (2017). Dampak Pemekaran Daerah Terhadap Kualitas Pelayanan Publik di Bidang Kesehatan (Studi Kasus di Kabupaten Muna Barat). Jimkesmas Jurnal Ilmiah Mahasiswa Kesehatan Masyarakat, 2(6), 1-10. ojs.uho.ac.id/index.php/JIMKESMAS/article/view/2895

Muttaqin, Z., \& Nurhadi. (2017). Rute Optimal Kendaraan Bermotor Berdasarkan Keterjangkauan Rumah Sakit Umum di Kota Yogyakarta. Geomedia, 15(2), $45-60$.

Nasir, J. A. (2011). Prolonging the Native Demographic Bonus : An Empirical Evidence. 2 (7), 104-110.

Nawiyanto. (2009). Pertumbuhan Penduduk Besuki: Kajian Demografi Historis. Humaniora, 21(2), 174-187. https://doi.org/10.22146/jh.v21i2.1328

Nisa Indahsari. (2018). Analisis Pola Spasial Fasilitas Pelayanan Kesehatan Terhadap Masyakarat di Kota Tegal. Universitas Muhammadiyah Surakarta.

Nurcahya, A. I. (2014). Jangkauan Wilayah Pelayanan Pasar Tradisional Somoroto di Kecamatan Kauman Kabupaten Ponorogo. Jurnal Wilayah Dan Lingkungan, 2(2), 157. https://doi.org/10.14710/jwl.2.2.157-168

Nurcaya, I. N. (2012). Analisis Kualitas Pelayanan Rumah Sakit Di Provinsi Bali. Piramida, 1-22.

Oppio, A., Buffoli, M., Ovo, M. D., \& Capolongo, S. (2016). Addressing Decisions About New Hospitals 'Siting: A Multidimensional Evaluation Approach. 52(1), 78-87. https://doi.org/10.4415/ANN

Organisation for Economic Co-Operation and Development (OECD). (2020). Hospital Beds (Indicator). https://data.oecd.org/healtheqt/hospital-beds.htm 
Peraturan Daerah Kabupaten Sumedang No 2 Tahun 2012 Tentang Rencana Tata Ruang Wilayah Kabupaten Sumedang Tahun 2011 - 2031.

Peraturan Menteri Kesehatan Nomor 24 Tahun 2016 Tentang Persyaratan Teknis Bangunan dan Prasarana Rumah Sakit.

Peraturan Menteri Kesehatan Nomor 56 Tahun 2014.

Peraturan Menteri Kesehatan Nomor 6 Tahun 2013 Tentang Fasilitas Pelayanan Kesehatan.

Peraturan Menteri Kesehatan Republik Indonesia Nomor 56 Tahun 2014 tentang Klasifikasi dan Perizinan Rumah Sakit.

Peraturan Pemerintah Republik Indonesia Nomor 47 Tahun 2016 Tentang Fasilitas Pelayanan Kesehatan Fasilitas Pasal 1 Ayat 1.

Peraturan Pemerintah Republik Indonesia Nomor 47 Tahun 2016 Tentang Fasilitas Pelayanan Kesehatan Pasal 4 Ayat 1.

Perwira, I. (2015). Memahami Kesehatan Sebagai Hak Asasi Manusia. Elsam:Referensi HAM.

Prahasta, E. (2009). Sistem Informasi Geografis: Konsep-Konsep Dasar. Informatika Bandung.

Pudjiantoro, R. (2008). Pengembangan Pelayanan Rumah Sakit Umum Daerah Tugurejo-Semarang [Universitas Diponegoro]. http://eprints.undip.ac.id/18805

Purnomo, S., Subiyanto, S., \& Nugraha, A. L. (2017). Analisis Potensi Peruntukan Lahan Rumah Sakit Dinilai Dari Aspek Fisik dan Kebutuhan Penduduk Dengan Sistem Informasi Geografis di Kota Semarang. Geodesi Undip, 2(Sistem Informasi Geografis), 240-252.

Qviström, M. (2015). Putting Accessibility in Place: A Relational Reading of Accessibility in Policies For Transit-Oriented Development. Geoforum, 58, 166-173. https://doi.org/10.1016/j.geoforum.2014.11.007 
Rahimi, F., Goli, A., \& Rezaee, R. (2017). Hospital Location-Allocation in Shiraz using Geographical Information System (GIS). Shiraz E Medical Journal, 18(8). https://doi.org/10.5812/semj.57572

Ratnaningrum, N., Yuwono, B. D., \& Awaluddin, M. (2014). Penentuan Jalur Optimal Menuju Stasiun Kereta Api Tawang Kota Semarang Menggunakan Analisis Jaringan. 4.

Rencana Jangka Panjang Menengah Daerah Kabupaten Sumedang 2018 - 2023.

Rinnasa, P.-A., Nababan, E. S. M., \& Bu'ulolo, F. (2013). Strategi Peningkatan Kualitas Pelayanan Kesehatan Menggunakan Integrasi Metode Fuzzy Servqual. Saintia Matematika, 1(6), 529-541.

Riyanto, Ekaputra, P., \& Indelarko, H. (2019). Pengembangan Aplikasi Sistem Informasi Geografis Berbasis Dekstop dan Web. Gava Media.

Rumahorbo, V. O. H. (2015). Kajian Yuridis Pendirian Rumah Sakit Menurut Undang-undang Nomor 44 Tahun 2009 Tentang Rumah Sakit. Ekp, 13(3), $1576-1580$.

S, A. (1989). Konservasi Tanah dan Air. IPB Press.

S, L. (2008). Pendekatan Pencegahan dan Penanggulangan Banjir. Dinamika Teknik Sipil, 8(2).

Saaty, T. L. (1993a). Pengambilan Keputuan Bagi Para Pemimpin, Proses Hirarki Analitik Untuk Pengambilan Keputusan Dalam Situasi Kompleks (Seri Manaj). PT. Pustaka Binama Pressindo.

Saaty, T. L. (1993b). The Analytical Hierarchy Process: Planning, Priority Setting, Resource Allocation. University of Pittsburgh Pers.

Sabar, R. (2007). Pengantar Metodologi Penelitian. FKIP Universitas Muria Kudus.

Samuel N, L., \& Loomba, P. (n.d.). Health Care Administration : “A Managerial perspective.” Fakultas Ekonomi Universitas Indonesia. 
Soepono, P. (1998). Peranan Daerah Perkotaan Bagi Pembangunan Regional: Penerapan Model Thunen yang Dimodifikasikan di Indonesia. Jurnal Ekonomi Dan Bisnis Indonesia, 13(2), 27.

Somantri, L. (2016). Pemanfaatan Citra Quickbird Dan Sistem Informasi Geografis Untuk Zonasi Kerentanan Kebakaran Permukiman Kasus Di Kota Bandung Bagian Barat. Jurnal Geografi Gea, 11(1), 86-101. https://doi.org/10.17509/gea.v11i1.1656

Sugito, N. T., \& Sugandi, D. (2009). Urgensi Sistem Informasi Geografis (SIG) Untuk Mendukung Data Geospasial. 1-11.

Sugiyono. (2009). Metode Penelitian Administrasi Dilengkapi Dengan Metode $R$ \& D. Alfabeta.

Sugiyono. (2011). Metode Penelitian Kuantitatif, Kualitatif, dan R\&D. Alfabeta.

Sumaatmadja, N. (1988). Studi Geografi Suatu Pendekatan dan Analisa Keruangan. Alumni.

Sumantri, S. H., Supriyatno, M., Sutisna, S., \& I Dewa Ketut Kerta Widana. (2019).

Sistem Informasi Geografis (Geographic Information System) Kerentanan Bencana (Issue December). CV. Makmur Cahaya Ilmu.

Sutanto. (1986). Penginderaan Jauh. Gadjah Mada University Press.

Tarigan R. (2006). Perencanaan Pembangunan Wilayah. Bumi Aksara.

Undang-undang Nomor 44 Tahun 2009 Tentang Rumah Sakit.

Undang-Undang Nomor 44 Tahun 2009 Tentang Rumah Sakit. (2009).

Undang-undang Republik Indonesia Nomor 23 Tahun 1992 Tentang Kesehatan.

Undang-undang Republik Indonesia Nomor 36 Tahun 2009 Pasal 30 Ayat 1.

Undang-undang Republik Indonesia Tentang Kesehatan Pasal 52 Ayat 2.

Vebnia, A., Pradhanawati, A., \& Nurseto, S. (2019). Pengaruh Fasilitas, Lokasi, dan Tarif Terhadap Loyalitas Melalui Kepuasan Pasien Sebagai Variabel Mediasi Pada Pasien Poli Rumah Sakit Muhammadiyah Semarang. Journal of xxiii 
Chemical Information and Modeling, 53(9), 1689-1699. https://doi.org/10.1017/CBO9781107415324.004

Vulevic, A. (2016). Accessibility Concepts and Indicators in Transportation Strategic Planning Issues: Theoretical Framework and Literature Review. Logistics \& Sustainable Transport, 7(1), 58-67. https://doi.org/10.1515/jlst2016-0006

Wang, F. (2020). Why Public Health Needs GIS: a Methodological Overview. Annals of GIS, 26(1), 1-12. https://doi.org/10.1080/19475683.2019.1702099

Warmansyah, J. (2010). Sistem Informasi Analitycal Hierarchy Procces(AHP) Sebagai Instrumen Pembantu Keputusan Dalam Pemilihan Saham. Jurnal Ilmiah Teknologi Dan Sains, 1.

Wegener, M. (2010). Accessibility and Development Impacts. Transport and Urban Development. https://doi.org/10.4324/9780203451328_chapter_11

Wirosuhardjo, K. (1986). Kebijaksanaan Kependudukan dan Ketenagakerjaan di Indonesia. Fakultas Ekonomi Universitas Indonesia.

Wu, C. R., Lin, C. T., \& Chen, H. C. (2009). Integrated Environmental Assessment of The Location Selection With Fuzzy Analytical Network Process. Quality and Quantity, 43(3), 351-380. https://doi.org/10.1007/s11135-007-9125-z

Youzi, H., Nemati, G., \& Emamgholi, S. (2018). The Optimized Location of Hospital Using an Integrated Approach GIS and Analytic Hierarchy Process: A Case Study of Kohdasht City. International Journal of Economics \& Management Sciences, 07(01), 1-6. https://doi.org/10.4172/21626359.1000500

Ziliwu, O. R. D., Witjaksono, A., \& Imaduddina, A. H. (n.d.). Penentuan Skala Pelayanan Pada Kawasan Perdaganagan Bagian Kota Malang Barat. 1-16. 
